\section{Cellular Physiology} and Biochemistry Published online: December 14, 2015

Accepted: November 27, 2015

\title{
Fucoxanthin Induced Suicidal Death of Human Erythrocytes
}

\author{
Marilena Brigliaa ${ }^{a, b}$ Salvatrice Calabróa,b Elena Signoretto ${ }^{d}$ Kousi Alzoubia \\ Stefan Laufer ${ }^{c}$ Caterina Faggio ${ }^{b}$ Florian Lang $^{\mathrm{a}}$
}

aDepartment of Physiology, University of Tübingen, Germany; ${ }^{b}$ Department of Chemical, Biological, Pharmaceutical and Environmental Sciences, University of Messina, S. Agata-Messina, Italy; Department of Pharmacy, University of Tübingen, Germany; ${ }^{d}$ Department of Pharmacological and Biomolecular Sciences, Università degli Studi di Milano, Milano, Italy

\section{Key Words}

Phosphatidylserine $\cdot$ Cell volume $\bullet$ Eryptosis $\bullet$ Oxidative stress $\bullet$ Calcium

\begin{abstract}
Background/Aims: Fucoxanthin, a carotenoid isolated from brown seaweeds, induces suicidal death or apoptosis of tumor cells and is thus considered for the treatment or prevention of malignancy. In analogy to apoptosis of nucleated cell, erythrocytes may enter eryptosis, the suicidal death characterized by cell shrinkage and cell membrane scrambling with phosphatidylserine translocation to the erythrocyte surface. Triggers of eryptosis include $\mathrm{Ca}^{2+}$ entry with increase of cytosolic $\mathrm{Ca}^{2+}$ activity $\left(\left[\mathrm{Ca}^{2+}\right]_{i}\right)$, oxidative stress and activation of p38 kinase or protein kinase C. The present study explored, whether and how fucoxanthin induces eryptosis. Methods: Phosphatidylserine exposure at the cell surface was estimated from annexin-V-binding, cell volume from forward scatter, hemolysis from hemoglobin release, $\left[\mathrm{Ca}^{2+}\right]_{i}$ from Fluo3-fluorescence, and abundance of reactive oxygen species (ROS) from DCFDA dependent fluorescence and lipid peroxidation using BODIPY fluoresence. Results: A 48 hours exposure of human erythrocytes to fucoxanthin significantly increased the percentage of annexin-V-binding cells $(\geq 50 \mu \mathrm{M})$, significantly decreased average forward scatter ( $\geq 25 \mu \mathrm{M})$, significantly increased hemolysis ( $\geq 25 \mu \mathrm{M})$, significantly increased Fluo3fluorescence $(\geq 50 \mu \mathrm{M})$, significantly increased lipid peroxidation, but did not significantly modify DCFDA fluorescence. The effect of fucoxanthin on annexin-V-binding was significantly blunted, but not abolished by removal of extracellular $\mathrm{Ca}^{2+}$, and was insensitive to p38 kinase inhibitor skepinone $(2 \mu \mathrm{M})$ and to protein kinase $C$ inhibitor calphostin $(100 \mathrm{nM})$. Conclusion: Fucoxanthin triggers cell shrinkage and phospholipid scrambling of the erythrocyte cell membrane, an effect in part due to stimulation of $\mathrm{Ca}^{2+}$ entry.
\end{abstract}




\section{Cellular Physiology Cell Physiol Biochem 2015;37:2464-2475 and Biochemistry \begin{tabular}{l|l} 
DOI: 10.1159/000438599 & (c) 2015 The Author(s). Published by S. Karger AG, Basel \\
www.karger.com/cpb
\end{tabular} \\ Briglia et al.: Fucoxanthin-Induced Eryptosis}

\section{Introduction}

Fucoxanthin, a carotenoid from the chloroplasts of brown seaweeds [1-3] and/or its metabolite fucoxanthinol [1] have anti-mutagenic [1], anti-obesity [1-8], anti-diabetic [1, 3, $5,6,8]$, antioxidant $[3,4,7,8]$, anti-inflammatory $[1,4,8]$, liver , skin, bone \& eye protective $[3,8]$, cardio- \& cerebrovascular protective $[3,4,8]$, anti-angiogenic [8], and antimalarial [8] activities.

Fucoxanthinol and to a lesser extent fucoxanthin triggers apoptosis [1,9-29] and is thus considered for the treatment or prevention of malignancy $[1,4,7,8,15-17,21,22,25,28-31]$. Signaling involved in the effect of fucoxanthin(ol) include NF- $\kappa B ~[1,21,24-27,30]$, p53 [10], caspases [1], Bcl-2 proteins [1, 30], MAPK [1, 30], PI3K/Akt [1, 23, 26, 27], JAK/STAT [1, 28], AP-1 [1], GADD45 [1, 30], increase of cytosolic $\mathrm{Ca}^{2+}$ activity [20], and caspases [10, 12, 15-19, $23,25,29,30]$. The substance is further partially effective by stimulating autophagy [14] and by depolarizing mitochondria $[5,6,27]$. On the other hand, partially due to its antioxidant activity, fucoxanthin may inhibit apoptosis [32, 33].

Even though lacking mitochondria and nuclei, erythrocytes may enter suicidal death or eryptosis, which is characterized by cell shrinkage [34] and by phospholipid scrambling of the cell membrane with phosphatidylserine translocation to the cell surface [35]. Eryptosis is stimulated by $\mathrm{Ca}^{2+}$ entry with increase of cytosolic $\mathrm{Ca}^{2+}$ activity $\left(\left[\mathrm{Ca}^{2+}\right]_{\mathrm{i}}\right)$, oxidative stress [35], ceramide [36], energy depletion [35], caspases [35, 37, 38], stimulation of casein kinase $1 \alpha$, Janus-activated kinase JAK3, protein kinase C, and p38 kinase [35], as well as pharmacological or genetic knockout of AMP activated kinase AMPK, cGMP-dependent protein kinase, and PAK2 kinase and sorafenib/sunitinib sensitive kinases [35]. Eryptosis is stimulated by a wide variety of xenobiotics [35, 39-63] and is enhanced in diverse clinical conditions, such as dehydration [52], hyperphosphatemia [62] chronic kidney disease (CKD) [44, 64-66], hemolytic-uremic syndrome [67], diabetes [68], hepatic failure [69], malignancy [35], sepsis [70], sickle-cell disease [35], beta-thalassemia [35], Hb-C and G6PD-deficiency [35], as well as Wilsons disease [71].

The present study explored whether and how fucoxanthin triggers eryptosis. To this end, human erythrocytes from healthy volunteers were exposed for 48 hours to fucoxanthin and phosphatidylserine surface abundance, cell volume as well as $\left[\mathrm{Ca}^{2+}\right]_{i}$ and ROS formation quantified by flow cytometry.

\section{Materials and Methods}

\section{Erythrocytes, solutions and chemicals}

Fresh Li-Heparin-anticoagulated blood samples were kindly provided by the blood bank of the University of Tübingen. The study is approved by the ethics committee of the University of Tübingen (184/2003 V). The blood was centrifuged at $120 \mathrm{~g}$ for $20 \mathrm{~min}$ at $21^{\circ} \mathrm{C}$ and the platelets and leukocytes-containing supernatant was disposed. Erythrocytes were incubated in vitro at a hematocrit of $0.4 \%$ in Ringer solution containing (in $\mathrm{mM}$ ) $125 \mathrm{NaCl}, 5 \mathrm{KCl}, 1 \mathrm{MgSO}_{4}, 32 \mathrm{~N}$-2-hydroxyethylpiperazine-N-2-ethanesulfonic acid (HEPES; pH 7.4), 5 glucose, $1 \mathrm{CaCl}_{2}$, at $37^{\circ} \mathrm{C}$ for $24 \mathrm{~h}$. Where indicated, erythrocytes were exposed to fucoxanthin (Sigma Aldrich, Hamburg, Germany), skepinone [72], or calphostin (Cayman, Ann Arbor, USA) at the indicated concentrations.

\section{Annexin-V-binding and forward scatter}

After incubation under the respective experimental condition, $100 \mu \mathrm{l}$ cell suspension was washed in Ringer solution containing $5 \mathrm{mM} \mathrm{CaCl}_{2}$ and then stained with Annexin-V-FITC (1:200 dilution; ImmunoTools, Friesoythe, Germany) in this solution at $37^{\circ} \mathrm{C}$ for $20 \mathrm{~min}$ under protection from light. The annexin-V abundance at the erythrocyte surface was subsequently determined on a FACS Calibur (BD, Heidelberg, Germany). A dot plot of forward scatter (FSC) vs. side scatter (SSC) was set to linear scale for both parameters. The threshold of forward scatter was set at the default value of " 52 ". 


\section{Cellular Physiology Cell Physiol Biochem 2015;37:2464-2475 \begin{tabular}{l|l|l} 
and Biochemistry $\begin{array}{l}\text { DOI: 10.1159/000438599 } \\
\text { Published online: December 14, } 2015\end{array}$ & $\begin{array}{l}\text { (c) } 2015 \text { The Author(s). Published by S. Karger AG, Basel } \\
\text { www.karger.com/cpb }\end{array}$
\end{tabular} \\ Briglia et al.: Fucoxanthin-Induced Eryptosis}

Hemolysis

For the determination of hemolysis, the samples were centrifuged (10 min at $2000 \mathrm{rpm}$, room temperature) after incubation under the respective experimental conditions and the supernatants were harvested. As a measure of hemolysis, the hemoglobin $(\mathrm{Hb})$ concentration of the supernatant was determined photometrically at $405 \mathrm{~nm}$. The absorption of the supernatant of erythrocytes lysed in distilled water was defined as $100 \%$ hemolysis.

Intracellular $\mathrm{Ca}^{2+}$

After incubation, erythrocytes were washed in Ringer solution and then loaded with Fluo-3/AM (Biotium, Hayward, USA) in Ringer solution containing $5 \mu \mathrm{M}$ Fluo-3/AM. The cells were incubated at $37^{\circ} \mathrm{C}$ for $30 \mathrm{~min}$ and washed once in Ringer solution containing $5 \mathrm{mM} \mathrm{CaCl}_{2}$. The Fluo-3/AM-loaded erythrocytes were resuspended in $200 \mu \mathrm{l}$ Ringer. Then, $\mathrm{Ca}^{2+}$-dependent fluorescence intensity was measured with an excitation wavelength of $488 \mathrm{~nm}$ and an emission wavelength of $530 \mathrm{~nm}$ on a FACS Calibur.

Reactive oxygen species (ROS)

Oxidative stress was determined utilizing 2',7'-dichlorodihydrofluorescein diacetate (DCFDA). After incubation, a $100 \mu \mathrm{l}$ suspension of erythrocytes was washed in Ringer solution and then stained with DCFDA (Sigma, Schnelldorf, Germany) in PBS containing DCFDA at a final concentration of $10 \mu \mathrm{M}$. Erythrocytes were incubated at $37^{\circ} \mathrm{C}$ for $30 \mathrm{~min}$ in the dark and then washed in PBS. The DCFDA-loaded erythrocytes were resuspended in $200 \mu \mathrm{l}$ Ringer solution, and ROS-dependent fluorescence intensity was measured at an excitation wavelength of $488 \mathrm{~nm}$ and an emission wavelength of $530 \mathrm{~nm}$ on a FACS Calibur (BD).

\section{Lipid peroxidation}

For detection of lipid peroxidation BODIPY 581/591 C11 (Thermo Fisher Scientific, MA, USA) was used. The nonoxidized dye has an emmission wavelength of $590 \mathrm{~nm}$ (FL2) and loses fluorescence to 510 $\mathrm{nm}$ (FL1) upon interaction with peroxyl radicals. Following the respective treatment, cells were loaded with $5 \mu \mathrm{M}$ BODIPY for $30 \mathrm{~min}$ at $37^{\circ} \mathrm{C}$ in the dark. Cells were collected and analyzed by FACS Calibur (BD) at emission wavelengths of $530 \mathrm{~nm}$ and $585 \mathrm{~nm}$.

\section{Thiazole Orange}

For studying the effect of fucoxanthin on the reticulocyte sub- population thiazole orange was used according to methods described previously [73]. Briefly, treated samples where stained with $1 \mu \mathrm{g} / \mathrm{ml}$ Thiazole orange for $30 \mathrm{~min}$ in the dark at $37^{\circ} \mathrm{C}$ and measured with an excitation wavelength of $488 \mathrm{~nm}$ and an emission wavelength of $530 \mathrm{~nm}$ on a FACS Calibur. Analysis of the plot of forward scatter vs. fluorescence of the stained samples enables the discrimination of reticulocytes from the rest of erythrocyte population, thereafter gates where set on the two population and binding to Annexin-V- Alexa Fluor ${ }^{\mathrm{TM}} 647$ (Thermo Fisher Scientific, MA, USA) and forward scatter was determined for each.

\section{Statistics}

Data are expressed as arithmetic means \pm SEM. As indicated in the figure legends, statistical analysis was made using ANOVA with Tukey's test as post-test and $t$ test as appropriate. $\mathrm{n}$ denotes the number of different erythrocyte specimens studied. Since different erythrocyte specimens used in distinct experiments are differently susceptible to triggers of eryptosis, the same erythrocyte specimens have been used for control and experimental conditions.

\section{Results}

The present study explored the putative effect of fucoxanthin on eryptosis, the suicidal erythrocyte death characterized by cell shrinkage and cell membrane scrambling with phosphatidylserine translocation to the cell surface. Annexin-V-binding was determined by flow cytometry in order to identify phosphatidylserine exposing erythrocytes. Prior to measurement, erythrocytes were incubated for 48 hours in Ringer solution without or with fucoxanthin $(25-75 \mu \mathrm{M})$. As illustrated in Fig. 1, a 48 hours exposure to fucoxanthin 
Fig. 1. Effect of fucoxanthin on phosphatidylserine exposure. A. Original histogram of annexin-V-binding of erythrocytes following exposure for 48 hours to Ringer solution without (grey area) and with (black line) presence of $75 \mu \mathrm{M}$ fucoxanthin. B. Arithmetic means $\pm \operatorname{SEM}(n=14)$ of erythrocyte annexinV-binding following incubation for 48 hours to Ringer solution without (white bar) or with (black bars) presence of fucoxanthin (25 - 75

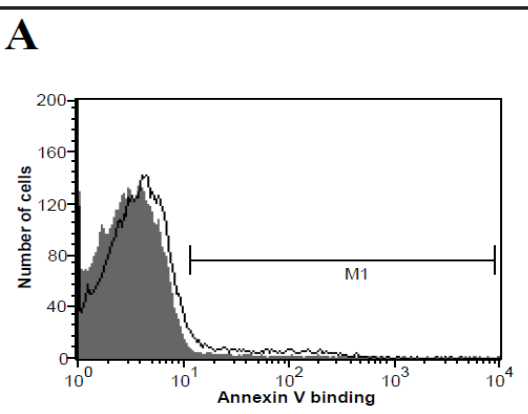

B

C

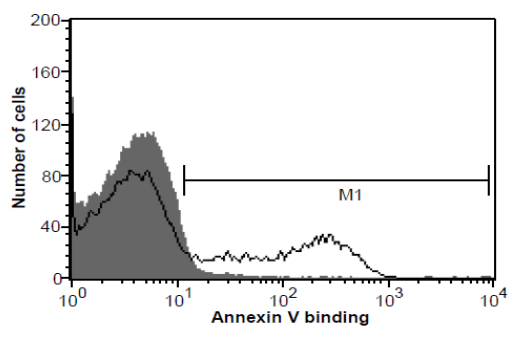

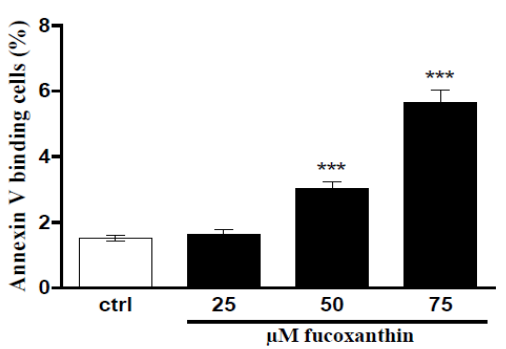

D

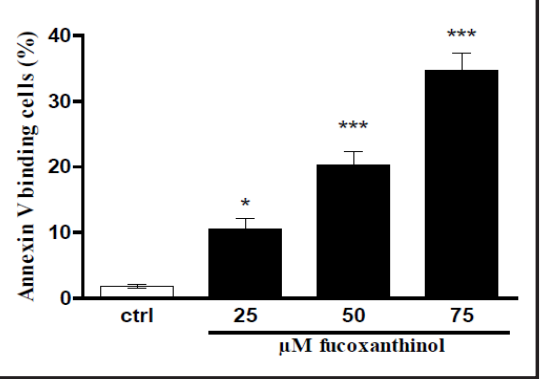
$\mu \mathrm{M})$. C. Original histogram of annexin-V-binding of erythrocytes following exposure for 48 hours to Ringer solution without (grey area) and with (black line) presence of $75 \mu \mathrm{M}$ fucoxanthinol. D. Arithmetic means \pm SEM $(n=4)$ of erythrocyte annexin-V-binding following incubation for 48 hours to Ringer solution without (white bar) or with (black bars) presence of fucoxanthinol $(25-75 \mu \mathrm{M}) .^{*}(\mathrm{p}<0.05),{ }^{* * *}(\mathrm{p}<0.001)$ indicates significant difference from the absence of fucoxanthin (ANOVA).

Fig. 2. Effect of fucoxanthin on erythrocyte forward scatter. A. Original histogram of forward scatter of erythrocytes following exposure for 48 hours to Ringer solution without (grey area) and with (black line) presence of 75 $\mu \mathrm{M}$ fucoxanthin. $\mathrm{B}$. Arithmetic means \pm SEM $(n=14)$ of the erythrocyte forward scatter (FSC) following incubation for 48 hours to Ringer solution without (white bar) or with (black

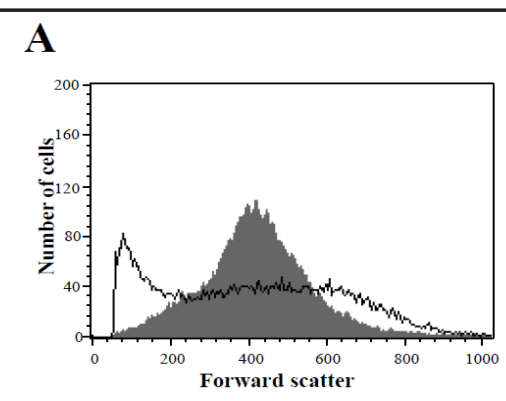

C

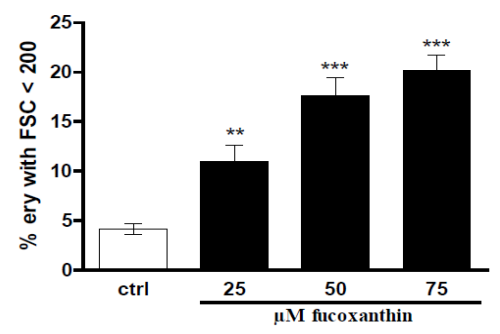

B

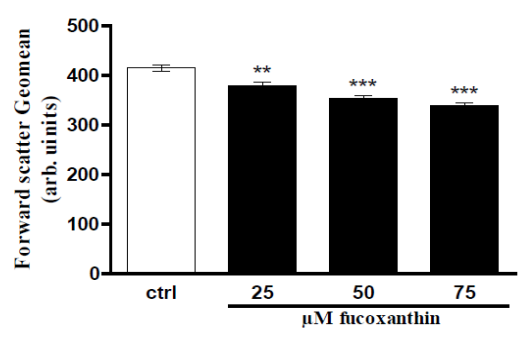

D

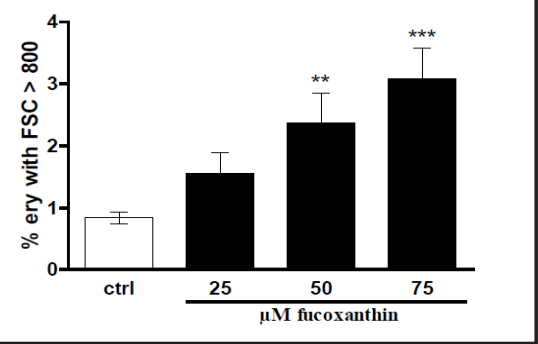

bars) fucoxanthin $(25-75 \mu \mathrm{M})$. C. Arithmetic means \pm SEM $(n=14)$ of the percentage erythrocytes with forward scatter (FSC) $<200$ following incubation for 48 hours to Ringer solution without (white bar) or with (black bars) fucoxanthin $(25-75 \mu \mathrm{M})$. D. Arithmetic means \pm SEM $(n=14)$ of the percentage erythrocytes with forward scatter (FSC) $>800$ following incubation for 48 hours to Ringer solution without (white bar) or with (black bars) fucoxanthin $(25-75 \mu \mathrm{M}) .{ }^{* *}(\mathrm{p}<0.01),{ }^{* * *}(\mathrm{p}<0.001)$ indicate significant difference from the absence of fucoxanthin (ANOVA).

\section{KARGER}




\section{Cellular Physiology Cell Physiol Biochem 2015;37:2464-2475

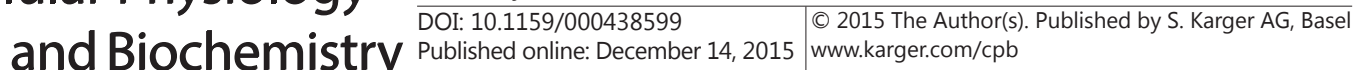 \\ Briglia et al.: Fucoxanthin-Induced Eryptosis}

Fig. 3. Effect of fucoxanthin on hemolysis. Arithmetic means \pm SEM $(n=10)$ of the percentage hemolysed erythrocytes following incubation for 48 hours to Ringer solution without (white bar) or with (black bars) presence of fucoxanthin (25 - 75 $\mu \mathrm{M}) .{ }^{* *}(\mathrm{p}<0.01),{ }^{* * *}(\mathrm{p}<0.001)$ indicates significant difference from the absence of fucoxanthin (ANOVA).

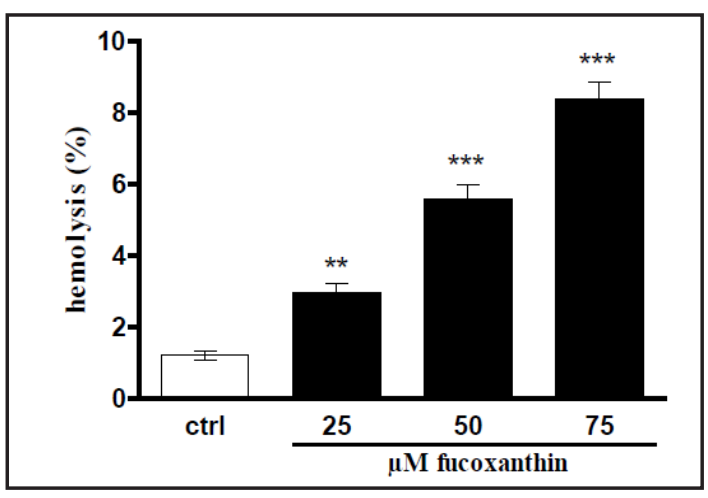

increased the percentage of phosphatidylserine exposing erythrocytes, an effect reaching statistical significance at $50 \mu \mathrm{M}$ fucoxanthin. Similarly, fucoxanthinol treatment for 48 hours increased the percentage of phosphatidylserine exposing erythrocytes, an effect reaching statistical significance at $25 \mu \mathrm{M}$.

Cell volume was estimated by determination of forward scatter with flow cytometry. Prior to measurements the erythrocytes were again incubated for 48 hours in Ringer solution without or with fucoxanthin $(25-75 \mu \mathrm{M})$. As shown in Fig, 2, fucoxanthin decreased the average erythrocyte forward scatter, an effect reaching statistical significance at $50 \mu \mathrm{M}$ fucoxanthin concentration. Inspection of the histogram reveals, however, that a subpopulation of erythrocytes underwent cell shrinkage but that another subpopulation of erythrocytes underwent cell swelling. Accordingly, exposure of erythrocytes to fucoxanthin was followed by an increase of the percentage of both small (Fig. 2C) and large (Fig. 2D) erythrocytes, alterations reaching significance at fucoxanthin concentrations of $25 \mu \mathrm{M}$ for small erythrocytes and $50 \mu \mathrm{M}$ for large erythrocytes. In order to explore whether fucoxanthin exerts opposing effects on reticulocytes and on mature erythrocytes, thiazole orange was utilized in order to identify reticulocytes. As a result, fucoxanthin increased the percentage reticulocytes binding annexin- $V$ from $15.6 \pm 1.8 \%$ to $25.1 \pm 1.7 \%(n=9)$ and the percentage of mature erythrocytes binding annexin-V from $6.7 \pm 1.3 \%$ to $16.0 \pm 0.9 \%(n=9)$. Fucoxanthin decreased forward scatter in reticulocytes from $810 \pm 46$ to $634 \pm 32(\mathrm{n}=9)$ and in mature erythrocytes from $716 \pm 19$ to $320 \pm 33.6(n=9)$. The respective values were not significantly different between reticulocytes and mature erythrocytes.

Further experiments addressed the putative effect of fucoxanthin on hemolysis. To this end, the hemoglobin concentration in the supernatant was determined by photometry. As illustrated in Fig. 3, a 48 hours incubation of erythrocytes in the presence of fucoxanthin was followed by a significant increase of the percentage of hemolytic erythrocytes, an effect reaching statistical significance at $25 \mu \mathrm{M}$ fucoxanthin concentration.

Fluo3-fluorescence was quantified in order to estimate cytosolic $\mathrm{Ca}^{2+}$ activity $\left(\left[\mathrm{Ca}^{2+}\right]_{\mathrm{i}}\right)$. As illustrated in Fig. 4, a 48 hours exposure to fucoxanthin increased the Fluo3-fluorescence, an effect reaching statistical significance at $50 \mu \mathrm{M}$ fucoxanthin. In order to test whether fucoxanthin -induced translocation of phosphatidylserine or erythrocyte shrinkage required entry of extracellular $\mathrm{Ca}^{2+}$, erythrocytes were incubated for 48 hours in the absence or presence of $75 \mu \mathrm{M}$ fucoxanthin in the presence or nominal absence of extracellular $\mathrm{Ca}^{2+}$. As shown in Fig 5, removal of extracellular $\mathrm{Ca}^{2+}$ significantly blunted the effect of fucoxanthin on annexin-V-binding. However, fucoxanthin significantly increased the percentage of annexinV-binding erythrocytes even in the absence extracellular $\mathrm{Ca}^{2+}$. Thus, fucoxanthin-induced cell membrane scrambling was partially but not completely due to entry of extracellular $\mathrm{Ca}^{2+}$.

In order to quantify reactive oxygen species (ROS) abundance, $2^{\prime}, 7^{\prime}$-dichlorodihydrofluorescein diacetate (DCFDA) fluorescence was determined utilizing flow cytometry. As a result, the ROS abundance was similar following a 48 hours exposure in the absence of fucoxanthin (18.2 \pm 0.7 a.u., $\mathrm{n}=10)$ and in the presence of $25 \mu \mathrm{M}(16.5 \pm 0.9$ a.u., $\mathrm{n}=10), 50$ $\mu \mathrm{M}(16.3 \pm 1.0$ a.u., $\mathrm{n}=10)$ and $75 \mu \mathrm{m}(17.6 \pm 0.9$ a.u., $\mathrm{n}=10)$ fucoxanthin. Thus, fucoxanthin did not induce appreciable oxidative stress. 
A

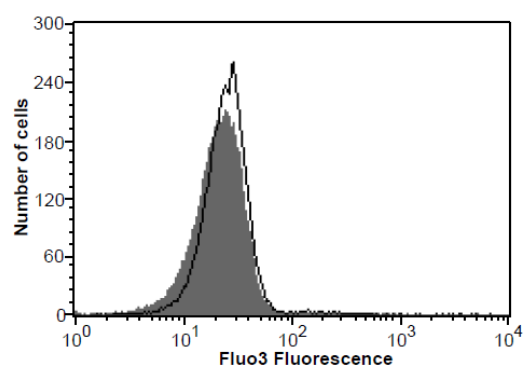

B

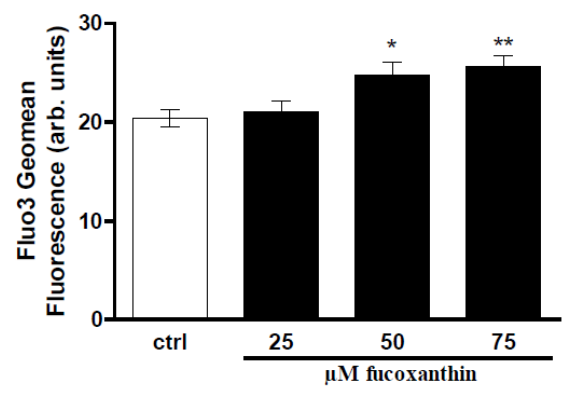

Fig. 4. Effect of fucoxanthin on erythrocyte $\mathrm{Ca}^{2+}$ activity. A. Original histogram of Fluo3-fluorescence in erythrocytes following exposure for 48 hours to Ringer solution without (grey area) and with (black line) presence of fucoxanthin $(75 \mu \mathrm{M})$. B. Arithmetic means \pm SEM $(n=14)$ of the Fluo3 fluorescence (arbitrary units) in erythrocytes exposed for 48 hours to Ringer solution without (white bar) or with (black bars) fucoxanthin $(25-75 \mu \mathrm{M}) .{ }^{*}(\mathrm{p}<0.05),{ }^{* * *}(\mathrm{p}<0.01)$ indicate significant difference from the absence of fucoxanthin (ANOVA).
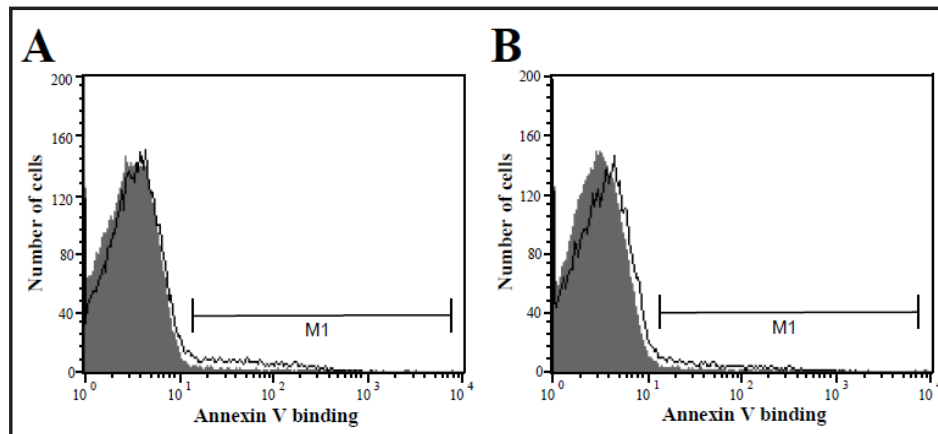

C

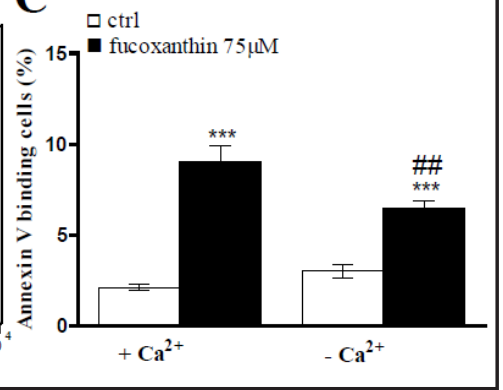

Fig. 5. $\mathrm{Ca}^{2+}$ sensitivity of fucoxanthin -induced phosphatidylserine exposure. A,B. Original histogram of annexin-V-binding of erythrocytes following exposure for 48 hours to Ringer solution without (grey area) and with (black line) presence of fucoxanthin $(75 \mu \mathrm{M})$ in the presence (A) and absence (B) of extracellular $\mathrm{Ca}^{2+}$.C. Arithmetic means \pm SEM $(n=10)$ of annexin-V-binding of erythrocytes after a 48 hours treatment with Ringer solution without (white bars) or with (black bars) fucoxanthin $(75 \mu \mathrm{M})$ in the presence (left bars, + $\left.\mathrm{Ca}^{2+}\right)$ and absence (right bars, $\left.-\mathrm{Ca}^{2+}\right)$ of $\mathrm{Ca}^{2+} .{ }^{* * *}(P<0.001)$ indicates significant difference from the absence of fucoxanthin, $\# \#(\mathrm{p}<0.01)$ indicate significant difference from the presence of $\mathrm{Ca}^{2+}$ (ANOVA).

In order to quantify lipid peroxidation, BODIPY 581/591 C11 fluorescence was determined in flow cytometry. As illustrated in Fig. 6, a 48 hours incubation of erythrocytes in the presence of fucoxanthin was followed by a significant increase of fluorescence of the oxidized form and significant decrease in the fluorescence of the nonoxidized form of BODIPY. Thus, fucoxanthin significantly increased lipid peroxidation.

To explore whether stimulation of annexin-V-binding by fucoxanthin required the activity of p38 kinase or protein kinase $\mathrm{C}$, experiments were performed in the absence and presence of the p38 kinase inhibitor skepinone $(2 \mu \mathrm{M})$ or of the protein kinase $\mathrm{C}$ inhibitor calphostin $(100 \mathrm{nM})$. As a result, a 48 hours exposure to fucoxanthin $(75 \mu \mathrm{M})$ increased the percentage of annexin-V-binding erythrocytes to a similar extent in the absence of the kinase inhibitors (from $2.0 \pm 0.3$ to $7.6 \pm 0.2 \%, \mathrm{n}=6$ ), the presence of skepinone (from $2.1 \pm 0.2$ to $6.8 \pm 0.3 \%, \mathrm{n}=6$ ), and in the presence of calphostin (from $2.1 \pm 0.3$ to $7.4 \pm 0.5 \%, \mathrm{n}=6$ ). Thus p38 kinase or protein kinase $C$ activities are apparently not required for the effect of fucoxanthin on erythrocyte cell membrane scrambling.

\section{KARGER}


A

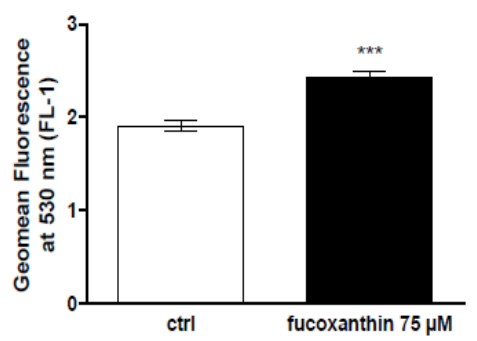

B

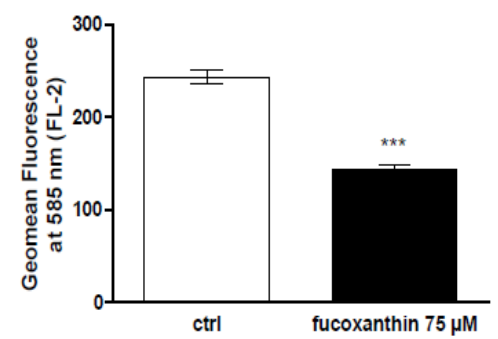

Fig. 6. Effect of fucoxanthin on lipid peroxidation. Arithmetic means \pm SEM $(n=9)$ of geomean fluorescence at (A) $530 \mathrm{~nm}$ and (B) $585 \mathrm{~nm}$ emission wavelength in erythrocytes exposed for 48 hours to Ringer solution without (white bars) or with (black bars) fucoxanthin $(75 \mu \mathrm{M}) .^{* * *}(P<0.001)$ indicates significant difference from the absence of fucoxanthin.

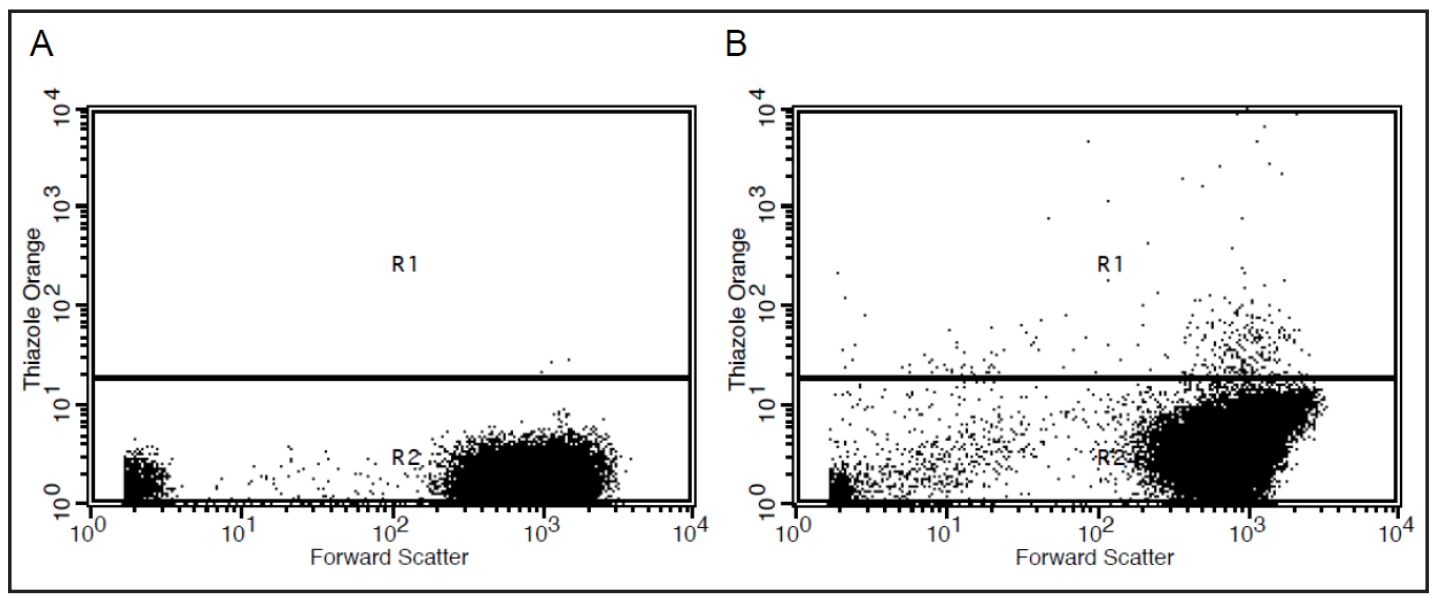

Fig. 7. Dot plots of thiazole orange staining. Original dot plots of forward scatter vs thiazole orange fluorescence in erythrocytes unstained (A) and Stained (B) with $1 \mu \mathrm{g} / \mathrm{ml}$ thiazole orange as prescribed in materials and methods, gates R1, R2 where set to determine reticulocytes from mature erythrocytes.

\section{Discussion}

The present observations disclose a novel effect of fucoxanthin, i.e. the triggering of eryptosis, the suicidal erythrocyte death. Treatment of human erythrocytes with fucoxanthin is followed by cell shrinkage and cell membrane scrambling with phosphatidylserine translocation to the erythrocyte surface.

The effect of fucoxanthin on cell membrane scrambling was in part due to increase of cytosolic $\mathrm{Ca}^{2+}$ activity $\left(\left[\mathrm{Ca}^{2+}\right]_{\mathrm{i}}\right)$, a well-known stimulator of cell membrane scrambling [35]. Accordingly, removal of extracellular $\mathrm{Ca}^{2+}$ significantly blunted the stimulation of cell membrane scrambling by fucoxanthin. $\mathrm{Ca}^{2+}$ entered presumably through $\mathrm{Ca}^{2+}$ permeable cation channels. Stimulators of those channels include oxidative stress [35]. However, according to DCFDA fluorescence, fucoxanthin treatment did not appreciably increase the abundance of reactive oxygen species. Moreover, stimulation of erythrocyte cell membrane scrambling by fucoxanthin did not require activation of skepinone and calphostin sensitive kinases.

Beyond its effect on cell membrane scrambling, the increase of $\left[\mathrm{Ca}^{2+}\right]_{\mathrm{i}}$ following fucoxanthin treatment is expected to activate $\mathrm{Ca}^{2+}$ sensitive $\mathrm{K}^{+}$channels with subsequent cell shrinkage due to $\mathrm{K}^{+}$exit, cell membrane hyperpolarization, $\mathrm{Cl}^{-}$exit and thus cellular loss of $\mathrm{KCl}$ with water [34]. Accordingly, the fucoxanthin treatment was followed by a significant decrease of the average forward scatter. However, close inspection of the histogram reveals that following fucoxanthin treatment a subpopulation of erythrocytes decreases, whereas another 


\section{Cellular Physiology Cell Physiol Biochem 2015;37:2464-2475

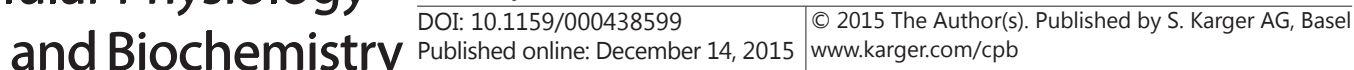 \\ Briglia et al.: Fucoxanthin-Induced Eryptosis}

subpopulation of erythrocytes increases forward scatter. Thus, fucoxanthin treatment leads to swelling of a subset of erythrocytes.

The results with thiazole orange staining suggest that fucoxanthin increased the percentage of annexin-V-binding reticulocytes and mature erythrocytes. The relative effect was higher in mature erythrocytes, an observation possibly pointing to enhanced susceptibility of mature erythrocytes. Enhanced susceptibility of aged erythrocytes to oxidative stress and eryptosis has been shown previously [74].

Erythrocyte swelling may eventually result in hemolysis. Hemolysis is followed by release of hemoglobin, which passes the renal glomerular filter, precipitates in the acidic lumen of renal tubules and thus occludes nephrons [75]. It is the purpose of eryptosis to clear defective erythrocytes from circulating blood prior to hemolysis [35]. Eryptosis further allows the clearance of erythrocytes infected with the malaria pathogen Plasmodium. In the infected host erythrocyte Plasmodium imposes oxidative stress, which activates the $\mathrm{Ca}^{2+}$-permeable erythrocyte cation channels $[35,76]$. The susceptibility of erythrocytes from carriers of sickle-cell trait, beta-thalassemia-trait, $\mathrm{Hb}-\mathrm{C}$ and G6PD-deficiency to eryptosis is enhanced and thus the clearance of infected erythrocytes accelerated. As a result parasitemia is decreased and the carriers of those blood disorders are partially protected against a severe course of malaria [35, 77-79]. A similar protection is provided by clinical conditions with accelerated eryptosis, such as iron deficiency [80], or by xenobiotics triggering eryptosis, such as lead [80], chlorpromazine [81] or NO synthase inhibitors [81]. If the additive effect of oxidative stress in infected erythrocytes imposed by the intracellular pathogen $[35,76]$ and the sensitizing effect of fucoxanthin to stimulators of eryptosis leads to the preferential eryptosis and clearance of infected erythrocytes, fucoxanthin treatment may be similarly beneficial for the clinical course of malaria.

However, excessisve eryptosis may lead to anemia as soon as it is not matched by a similar increase of erythropoiesis [35]. Moreover, stimulation of eryptosis may impair microcirculation [36, 82-86] by adherence of phosphatidylserine exposing erythrocytes to the vascular wall [87], stimulation of blood clotting and triggering of thrombosis [82, 88, 89].

\section{Conclusion}

Fucoxanthin triggers eryptosis with cell shrinkage and cell membrane scrambling, an effect paralleled by and in part due to increase of cytosolic $\mathrm{Ca}^{2+}$ activity.

\section{Acknowledgements}

The authors acknowledge the meticulous preparation of the manuscript by Tanja Loch. The study was supported by the Deutsche Forschungsgemeinschaft and Open Access Publishing Fund of Tuebingen University.

\section{Disclosure Statement}

The sponsor have had played no role in study design, in the collection, analysis and interpretation of data, in the writing of the report and in the decision to submit the article for publication.

\section{References}

1 Martin LJ: Fucoxanthin and Its Metabolite Fucoxanthinol in Cancer Prevention and Treatment. Mar Drugs 2015;13:4784-4798. 


\section{Cellular Physiology Cell Physiol Biochem 2015;37:2464-2475 \begin{tabular}{l|l|l|l} 
DOI: 10.1159/000438599 & $\begin{array}{l}\text { C } 2015 \text { The Author(s). Published by S. Karger AG, Basel } \\
\text { www.karger.com/cpb }\end{array}$
\end{tabular} \\ Briglia et al.: Fucoxanthin-Induced Eryptosis}

2 Gammone MA, D'Orazio N: Anti-obesity activity of the marine carotenoid fucoxanthin. Mar Drugs 2015;13:2196-2214.

3 Muradian K, Vaiserman A, Min KJ, Fraifeld VE: Fucoxanthin and lipid metabolism: A minireview. Nutr Metab Cardiovasc Dis 2015;10.1016/j.numecd.2015.05.010

4 Kim SK, Pangestuti R: Biological activities and potential health benefits of fucoxanthin derived from marine brown algae. Adv Food Nutr Res 2011;64:111-128.

5 Maeda H: Nutraceutical effects of fucoxanthin for obesity and diabetes therapy: a review. J Oleo Sci 2015;64:125-132.

6 Miyashita K, Nishikawa S, Beppu F, Tsukui T, Abe M, Hosokawa M: The allenic carotenoid fucoxanthin, a novel marine nutraceutical from brown seaweeds. J Sci Food Agric 2011;91:1166-1174.

7 Muthuirulappan S, Francis SP: Anti-cancer mechanism and possibility of nano-suspension formulations for a marine algae product fucoxanthin. Asian Pac J Cancer Prev 2013;14:2213-2216.

8 Peng J, Yuan JP, Wu CF, Wang JH: Fucoxanthin, a marine carotenoid present in brown seaweeds and diatoms: metabolism and bioactivities relevant to human health. Mar Drugs 2011;9:1806-1828.

9 Wang J, Chen S, Xu S, Yu X, Ma D, Hu X, Cao X: In vivo induction of apoptosis by fucoxanthin, a marine carotenoid, associated with down-regulating STAT3/EGFR signaling in sarcoma 180 (S180) xenograftsbearing mice. Mar Drugs 2012;10:2055-2068.

10 Wang L, Zeng Y, Liu Y, Hu X, Li S, Wang Y, Li L, Lei Z, Zhang Z: Fucoxanthin induces growth arrest and apoptosis in human bladder cancer T24 cells by up-regulation of p21 and down-regulation of mortalin. Acta Biochim Biophys Sin (Shanghai) 2014;46:877-884.

11 Das SK, Hashimoto T, Shimizu K, Yoshida T, Sakai T, Sowa Y, Komoto A, Kanazawa K: Fucoxanthin induces cell cycle arrest at G0/G1 phase in human colon carcinoma cells through up-regulation of p21WAF1/Cip1. Biochim Biophys Acta 2005;1726:328-335.

12 Das SK, Ren R, Hashimoto T, Kanazawa K: Fucoxanthin induces apoptosis in osteoclast-like cells differentiated from RAW264.7 cells. J Agric Food Chem 2010;58:6090-6095.

13 Hosokawa M, Kudo M, Maeda H, Kohno H, Tanaka T, Miyashita K: Fucoxanthin induces apoptosis and enhances the antiproliferative effect of the PPARgamma ligand, troglitazone, on colon cancer cells. Biochim Biophys Acta 2004;1675:113-119.

14 Hou LL, Gao C, Chen L, Hu GQ Xie SQ: Essential role of autophagy in fucoxanthin-induced cytotoxicity to human epithelial cervical cancer HeLa cells. Acta Pharmacol Sin 2013;34:1403-1410.

15 Ishikawa C, Tafuku S, Kadekaru T, Sawada S, Tomita M, Okudaira T, Nakazato T, Toda T, Uchihara JN, Taira N, Ohshiro K, Yasumoto T, Ohta T, Mori N: Anti-adult T-cell leukemia effects of brown algae fucoxanthin and its deacetylated product, fucoxanthinol. Int J Cancer 2008;123:2702-2712.

16 Kim KN, Ahn G, Heo SJ, Kang SM, Kang MC, Yang HM, Kim D, Roh SW, Kim SK, Jeon BT, Park PJ, Jung WK, Jeon YJ: Inhibition of tumor growth in vitro and in vivo by fucoxanthin against melanoma B16F10 cells. Environ Toxicol Pharmacol 2013;35:39-46.

17 Kim KN, Heo SJ, Kang SM, Ahn G, Jeon YJ: Fucoxanthin induces apoptosis in human leukemia HL-60 cells through a ROS-mediated Bcl-xL pathway. Toxicol In Vitro 2010;24:1648-1654.

18 Kotake-Nara E, Asai A, Nagao A: Neoxanthin and fucoxanthin induce apoptosis in PC-3 human prostate cancer cells. Cancer Lett 2005;220:75-84.

19 Kotake-Nara E, Terasaki M, Nagao A: Characterization of apoptosis induced by fucoxanthin in human promyelocytic leukemia cells. Biosci Biotechnol Biochem 2005;69:224-227.

20 Liu CL, Huang YS, Hosokawa M, Miyashita K, Hu ML: Inhibition of proliferation of a hepatoma cell line by fucoxanthin in relation to cell cycle arrest and enhanced gap junctional intercellular communication. Chem Biol Interact 2009;182:165-172.

21 Liu CL, Lim YP, Hu ML: Fucoxanthin enhances cisplatin-induced cytotoxicity via NFkappaB-mediated pathway and downregulates DNA repair gene expression in human hepatoma HepG2 cells. Mar Drugs 2013;11:50-66.

22 Rengarajan T, Rajendran P, Nandakumar N, Balasubramanian MP, Nishigaki I: Cancer preventive efficacy of marine carotenoid fucoxanthin: cell cycle arrest and apoptosis. Nutrients 2013;5:4978-4989.

23 Rokkaku T, Kimura R, Ishikawa C, Yasumoto T, Senba M, Kanaya F, Mori N: Anticancer effects of marine carotenoids, fucoxanthin and its deacetylated product, fucoxanthinol, on osteosarcoma. Int J Oncol 2013;43:1176-1186. 


\section{Cellular Physiology Cell Physiol Biochem 2015;37:2464-2475 \begin{tabular}{l|l|l} 
DOI: 10.1159/000438599 & $\begin{array}{l}\text { @ } 2015 \text { The Author(s). Published by S. Karger AG, Basel } \\
\text { www.karger.com/cpb }\end{array}$
\end{tabular} \\ Briglia et al.: Fucoxanthin-Induced Eryptosis}

24 Rwigemera A, Mamelona J, Martin LJ: Comparative effects between fucoxanthinol and its precursor fucoxanthin on viability and apoptosis of breast cancer cell lines MCF-7 and MDA-MB-231. Anticancer Res 2015;35:207-219.

25 Tafuku S, Ishikawa C, Yasumoto T, Mori N: Anti-neoplastic effects of fucoxanthin and its deacetylated product, fucoxanthinol, on Burkitt's and Hodgkin's lymphoma cells. Oncol Rep 2012;28:1512-1518.

26 Yamamoto K, Ishikawa C, Katano H, Yasumoto T, Mori N: Fucoxanthin and its deacetylated product, fucoxanthinol, induce apoptosis of primary effusion lymphomas. Cancer Lett 2011;300:225-234.

27 Ye G, Lu Q, Zhao W, Du D, Jin L, Liu Y: Fucoxanthin induces apoptosis in human cervical cancer cell line HeLa via PI3K/Akt pathway. Tumour Biol 2014;35:11261-11267.

28 Yu RX, Hu XM, Xu SQ, Jiang ZJ, Yang W: Effects of fucoxanthin on proliferation and apoptosis in human gastric adenocarcinoma MGC-803 cells via JAK/STAT signal pathway. Eur J Pharmacol 2011;657:10-19.

29 Zhang Z, Zhang P, Hamada M, Takahashi S, Xing G, Liu J, Sugiura N: Potential chemoprevention effect of dietary fucoxanthin on urinary bladder cancer EJ-1 cell line. Oncol Rep 2008;20:1099-1103.

30 Kumar SR, Hosokawa M, Miyashita K: Fucoxanthin: a marine carotenoid exerting anti-cancer effects by affecting multiple mechanisms. Mar Drugs 2013;11:5130-5147.

31 Zorofchian Moghadamtousi S, Karimian H, Khanabdali R, Razavi M, Firoozinia M, Zandi K, Abdul Kadir $\mathrm{H}$ : Anticancer and antitumor potential of fucoidan and fucoxanthin, two main metabolites isolated from brown algae. ScientificWorldJournal 2014;2014:768323.

32 Kaneko M, Nagamine T, Nakazato K, Mori M: The anti-apoptotic effect of fucoxanthin on carbon tetrachloride-induced hepatotoxicity. J Toxicol Sci 2013;38:115-126.

33 Zheng J, Piao MJ, Keum YS, Kim HS, Hyun JW: Fucoxanthin Protects Cultured Human Keratinocytes against Oxidative Stress by Blocking Free Radicals and Inhibiting Apoptosis. Biomol Ther (Seoul) 2013;21:270276.

34 Lang PA, Kaiser S, Myssina S, Wieder T, Lang F, Huber SM: Role of Ca2+-activated K+ channels in human erythrocyte apoptosis. Am J Physiol Cell Physiol 2003;285:C1553-C1560.

35 Lang F, Qadri SM: Mechanisms and significance of eryptosis, the suicidal death of erythrocytes. Blood Purif 2012;33:125-130.

36 Abed M, Towhid ST, Mia S, Pakladok T, Alesutan I, Borst O, Gawaz M, Gulbins E, Lang F: Sphingomyelinaseinduced adhesion of eryptotic erythrocytes to endothelial cells. Am J Physiol Cell Physiol 2012;303:C991999.

37 Lau IP, Chen H, Wang J, Ong HC, Leung KC, Ho HP, Kong SK: In vitro effect of CTAB- and PEG-coated gold nanorods on the induction of eryptosis/erythroptosis in human erythrocytes. Nanotoxicology 2012;6:847856.

38 Maellaro E, Leoncini S, Moretti D, Del Bello B, Tanganelli I, De Felice C, Ciccoli L: Erythrocyte caspase-3 activation and oxidative imbalance in erythrocytes and in plasma of type 2 diabetic patients. Acta Diabetol 2013;50:489-495.

39 Jilani K, Lang F: Carmustine-induced phosphatidylserine translocation in the erythrocyte membrane. Toxins (Basel) 2013;5:703-716.

40 Vota DM, Maltaneri RE, Wenker SD, Nesse AB, Vittori DC: Differential erythropoietin action upon cells induced to eryptosis by different agents. Cell Biochem Biophys 2013;65:145-157.

41 Zappulla D: Environmental stress, erythrocyte dysfunctions, inflammation, and the metabolic syndrome: adaptations to CO2 increases? J Cardiometab Syndr 2008;3:30-34.

42 Lupescu A, Jilani K, Zbidah M, Lang F: Patulin-induced suicidal erythrocyte death. Cell Physiol Biochem 2013;32:291-299.

43 Abed M, Zoubi KA, Theurer M, Lang F: Effect of dermaseptin on erythrocytes. Basic Clin Pharmacol Toxicol 2013;113:347-352.

44 Ahmed MS, Langer H, Abed M, Voelkl J, Lang F: The uremic toxin acrolein promotes suicidal erythrocyte death. Kidney Blood Press Res 2013;37:158-167.

45 Ghashghaeinia M, Cluitmans JC, Toulany M, Saki M, Koberle M, Lang E, Dreischer P, Biedermann T, Duszenko M, Lang F, Bosman GJ, Wieder T: Age Sensitivity of NFkappaB Abundance and Programmed Cell Death in Erythrocytes Induced by NFkappaB Inhibitors. Cell Physiol Biochem 2013;32:801-813.

46 Alzoubi K, Honisch S, Abed M, Lang F: Triggering of Suicidal Erythrocyte Death by Penta-O-galloyl-beta-dglucose. Toxins (Basel) 2014;6:54-65. 


\section{Cellular Physiology Cell Physiol Biochem 2015;37:2464-2475 \begin{tabular}{l|l|l} 
DOI: 10.1159/000438599 & $\begin{array}{l}\text { C } 2015 \text { The Author(s). Published by S. Karger AG, Basel } \\
\text { www.karger.com/cpb }\end{array}$
\end{tabular} \\ Briglia et al.: Fucoxanthin-Induced Eryptosis}

47 Jilani K, Enkel S, Bissinger R, Almilaji A, Abed M, Lang F: Fluoxetine induced suicidal erythrocyte death. Toxins (Basel) 2013;5:1230-1243.

48 Lupescu A, Bissinger R, Jilani K, Lang F: Triggering of suicidal erythrocyte death by celecoxib. Toxins (Basel) 2013;5:1543-1554.

49 Arnold M, Lang E, Modicano P, Bissinger R, Faggio C, Abed M, Lang F: Effect of nitazoxanide on erythrocytes. Basic Clin Pharmacol Toxicol 2014;114:421-426.

50 Oswald G, Alzoubi K, Abed M, Lang F: Stimulation of suicidal erythrocyte death by ribavirin. Basic Clin Pharmacol Toxicol 2014;114:311-317.

51 Lupescu A, Bissinger R, Herrmann T, Oswald G, Jilani K, Lang F: Induction of suicidal erythrocyte death by novobiocin. Cell Physiol Biochem 2014;33:670-680.

52 Abed M, Feger M, Alzoubi K, Pakladok T, Frauenfeld L, Geiger C, Towhid ST, Lang F: Sensitization of erythrocytes to suicidal erythrocyte death following water deprivation. Kidney Blood Press Res 2013;37:567-578.

53 Alzoubi K, Calabròa S, Bissinger R, Abed M, Faggio C, Lang F: Stimulation of Suicidal Erythrocyte Death by Artesunate. Cell Physiol Biochem 2014;34:2232-2244.

54 Arnold M, Bissinger R, Lang F: Mitoxantrone-induced suicidal erythrocyte death. Cell Physiol Biochem 2014;34:1756-1767.

55 Bissinger R, Fischer S, Jilani K, Lang F: Stimulation of Erythrocyte Death by Phloretin. Cell Physiol Biochem 2014;34:2256-2265.

56 Bissinger R, Lupescu A, Zelenak C, Jilani K, Lang F: Stimulation of eryptosis by cryptotanshinone. Cell Physiol Biochem 2014;34:432-442.

57 Bissinger R, Modicano P, Frauenfeld L, Lang E, Jacobi J, Faggio C, Lang F: Estramustine-induced suicidal erythrocyte death. Cell Physiol Biochem 2013;32:1426-1436.

58 Jacobi J, Lang E, Bissinger R, Frauenfeld L, Modicano P, Faggio C, Abed M, Lang F: Stimulation of erythrocyte cell membrane scrambling by mitotane. Cell Physiol Biochem 2014;33:1516-1526.

59 Lupescu A, Bissinger R, Warsi J, Jilani K, Lang F: Stimulation of erythrocyte cell membrane scrambling by gedunin. Cell Physiol Biochem 2014;33:1838-1848.

60 Malik A, Bissinger R, Calabro S, Faggio C, Jilani K, Lang F: Aristolochic Acid Induced Suicidal Erythrocyte Death. Kidney Blood Press Res 2014;39:408-419.

61 Tesoriere L, Attanzio A, Allegra M, Cilla A, Gentile C, Livrea MA: Oxysterol mixture in hypercholesterolemiarelevant proportion causes oxidative stress-dependent eryptosis. Cell Physiol Biochem 2014;34:10751089.

62 Voelkl J, Alzoubi K, Mamar AK, Ahmed MS, Abed M, Lang F: Stimulation of suicidal erythrocyte death by increased extracellular phosphate concentrations. Kidney Blood Press Res 2013;38:42-51.

63 Zhang R, Xiang Y, Ran Q, Deng X, Xiao Y, Xiang L, Li Z: Involvement of calcium, reactive oxygen species, and ATP in hexavalent chromium-induced damage in red blood cells. Cell Physiol Biochem 2014;34:1780-1791.

64 Abed M, Artunc F, Alzoubi K, Honisch S, Baumann D, Foller M, Lang F: Suicidal erythrocyte death in endstage renal disease. J Mol Med (Berl) 2014;92:871-879.

65 Polak-Jonkisz D, Purzyc L: Ca(2+) influx versus efflux during eryptosis in uremic erythrocytes. Blood Purif 2012;34:209-210; author reply 210.

66 Calderon-Salinas JV, Munoz-Reyes EG, Guerrero-Romero JF, Rodriguez-Moran M, Bracho-Riquelme RL, Carrera-Gracia MA, Quintanar-Escorza MA: Eryptosis and oxidative damage in type 2 diabetic mellitus patients with chronic kidney disease. Mol Cell Biochem 2011;357:171-179.

67 Lang PA, Beringer O, Nicolay JP, Amon O, Kempe DS, Hermle T, Attanasio P, Akel A, Schafer R, Friedrich B, Risler T, Baur M, Olbricht CJ, Zimmerhackl LB, Zipfel PF, Wieder T, Lang F: Suicidal death of erythrocytes in recurrent hemolytic uremic syndrome. J Mol Med (Berl) 2006;84:378-388.

68 Nicolay JP, Schneider J, Niemoeller OM, Artunc F, Portero-Otin M, Haik G, Jr., Thornalley PJ, Schleicher E, Wieder T, Lang F: Stimulation of suicidal erythrocyte death by methylglyoxal. Cell Physiol Biochem 2006;18:223-232.

69 Lang E, Gatidis S, Freise NF, Bock H, Kubitz R, Lauermann C, Orth HM, Klindt C, Schuier M, Keitel V, Reich M, Liu G, Schmidt S, Xu HC, Qadri SM, Herebian D, Pandyra AA, Mayatepek E, Gulbins E, Lang F, Haussinger D, Lang KS, Foller M, Lang PA: Conjugated bilirubin triggers anemia by inducing erythrocyte death. Hepatology 2015;61:275-284. 


\section{Cellular Physiology Cell Physiol Biochem 2015;37:2464-2475 \begin{tabular}{l|l|l|} 
and BOI: 10.1159/000438599 & $\begin{array}{l}\text { @ } 2015 \text { The Author(s). Published by S. Karger AG, Basel } \\
\text { www.karger.com/cpb }\end{array}$
\end{tabular} \\ Briglia et al.: Fucoxanthin-Induced Eryptosis}

70 Kempe DS, Akel A, Lang PA, Hermle T, Biswas R, Muresanu J, Friedrich B, Dreischer P, Wolz C, Schumacher U, Peschel A, Gotz F, Doring G, Wieder T, Gulbins E, Lang F: Suicidal erythrocyte death in sepsis. J Mol Med (Berl) 2007;85:273-281.

71 Lang PA, Schenck M, Nicolay JP, Becker JU, Kempe DS, Lupescu A, Koka S, Eisele K, Klarl BA, Rubben H, Schmid KW, Mann K, Hildenbrand S, Hefter H, Huber SM, Wieder T, Erhardt A, Haussinger D, Gulbins E, Lang F: Liver cell death and anemia in Wilson disease involve acid sphingomyelinase and ceramide. Nat Med 2007;13:164-170.

72 Koeberle SC, Romir J, Fischer S, Koeberle A, Schattel V, Albrecht W, Grutter C, Werz O, Rauh D, Stehle T, Laufer SA: Skepinone-L is a selective p38 mitogen-activated protein kinase inhibitor. Nat Chem Biol 2012;8:141-143.

73 Lee LG, Chen CH, Chiu LA: Thiazole orange: a new dye for reticulocyte analysis. Cytometry 1986;7:508-517.

74 Ghashghaeinia M, Cluitmans JC, Akel A, Dreischer P, Toulany M, Koberle M, Skabytska Y, Saki M, Biedermann T, Duszenko M, Lang F, Wieder T, Bosman GJ: The impact of erythrocyte age on eryptosis. Br J Haematol 2012;157:606-614.

75 Harrison HE, Bunting H, Ordway NK, Albrink WS: The Pathogenesis of the Renal Injury Produced in the Dog by Hemoglobin or Methemoglobin. J Exp Med 1947;86:339-356.

76 Kirk K: Membrane transport in the malaria-infected erythrocyte. Physiol Rev 2001;81:495-537.

77 Ayi K, Giribaldi G, Skorokhod A, Schwarzer E, Prendergast PT, Arese P: 16alpha-bromoepiandrosterone, an antimalarial analogue of the hormone dehydroepiandrosterone, enhances phagocytosis of ring stage parasitized erythrocytes: a novel mechanism for antimalarial activity. Antimicrob Agents Chemother 2002;46:3180-3184.

78 Ayi K, Turrini F, Piga A, Arese P: Enhanced phagocytosis of ring-parasitized mutant erythrocytes: a common mechanism that may explain protection against falciparum malaria in sickle trait and beta-thalassemia trait. Blood 2004;104:3364-3371.

79 Cappadoro M, Giribaldi G, O'Brien E, Turrini F, Mannu F, Ulliers D, Simula G, Luzzatto L, Arese P: Early phagocytosis of glucose-6-phosphate dehydrogenase (G6PD)-deficient erythrocytes parasitized by Plasmodium falciparum may explain malaria protection in G6PD deficiency. Blood 1998;92:2527-2534.

80 Koka S, Huber SM, Boini KM, Lang C, Foller M, Lang F: Lead decreases parasitemia and enhances survival of Plasmodium berghei-infected mice. Biochem Biophys Res Commun 2007;363:484-489.

81 Koka S, Lang C, Niemoeller OM, Boini KM, Nicolay JP, Huber SM, Lang F: Influence of NO synthase inhibitor L-NAME on parasitemia and survival of Plasmodium berghei infected mice. Cell Physiol Biochem 2008;21:481-488.

82 Andrews DA, Low PS: Role of red blood cells in thrombosis. Curr Opin Hematol 1999;6:76-82.

83 Closse C, Dachary-Prigent J, Boisseau MR: Phosphatidylserine-related adhesion of human erythrocytes to vascular endothelium. Br J Haematol 1999;107:300-302.

84 Gallagher PG, Chang SH, Rettig MP, Neely JE, Hillery CA, Smith BD, Low PS: Altered erythrocyte endothelial adherence and membrane phospholipid asymmetry in hereditary hydrocytosis. Blood 2003;101:46254627.

85 Pandolfi A, Di Pietro N, Sirolli V, Giardinelli A, Di Silvestre S, Amoroso L, Di Tomo P, Capani F, Consoli A, Bonomini M: Mechanisms of uremic erythrocyte-induced adhesion of human monocytes to cultured endothelial cells. J Cell Physiol 2007;213:699-709.

86 Wood BL, Gibson DF, Tait JF: Increased erythrocyte phosphatidylserine exposure in sickle cell disease: flowcytometric measurement and clinical associations. Blood 1996;88:1873-1880.

87 Borst O, Abed M, Alesutan I, Towhid ST, Qadri SM, Foller M, Gawaz M, Lang F: Dynamic adhesion of eryptotic erythrocytes to endothelial cells via CXCL16/SR-PSOX. Am J Physiol Cell Physiol 2012;302:C644-C651.

88 Chung SM, Bae ON, Lim KM, Noh JY, Lee MY, Jung YS, Chung JH: Lysophosphatidic acid induces thrombogenic activity through phosphatidylserine exposure and procoagulant microvesicle generation in human erythrocytes. Arterioscler Thromb Vasc Biol 2007;27:414-421.

89 Zwaal RF, Comfurius P, Bevers EM: Surface exposure of phosphatidylserine in pathological cells. Cell Mol Life Sci 2005;62:971-988. 